\title{
CALCAREOLS NANNOPLANKTON RECOVERY FROM THE CRETACEOUS / TERTIARY MASS-EXTINCTION EVENT IN BJALA SECTION, EAST BULGARIA
}

STOYKOVA*, Kristalina H., Geological Institute of Bulgarian Academy of Sciences, 24 G. Boncev str., Sofia, BG-1113, Bulgaria

Calcareous nannofossils from the Cretaceous/Tertiary $(\mathrm{K} / \mathrm{T})$ boundary interval in the complete section at Bjala, Black Sea coast (East Bulgaria) were studied in order to document their response to the $\mathrm{K} / \mathrm{T}$ boundary event(s) and to show the pattern of their survival and recovery. The interval studied represents over $80 \mathrm{~m}$ thick sedimentary sequence, biostratigraphically subdivided to the CC26 Micula prinsii (Uppermost Maastrichtian), NP 1 Biantholithus sparsus, NP 2 Cruciplacolithus tenuis and NP 3 Chiasmolithus damicus (Lower Danian) nannofossil Zones. The $\mathrm{K} / \mathrm{T}$ boundary is marked by a clay bed ( 2 to $6 \mathrm{~cm}$ thickness) with an iridium anomaly.

Diversity and abundance of nannofossil assemblages in the last $1 \mathrm{~m}$ of the Uppermost Maastrichtian (CC $26 \mathrm{M}$. prinsii Zone) are relatively high, comprising over 40 species.

A drastic reduction in nannofossil abundance and diversity and mass-extinction of the Cretaceous taxa occurred at the boundary clay bed. It is practically devoid of nannofossils and only fragments of poorly preserved Thoracosphaera, Braarudosphaera and Cyclagelosphaera occur rarely.

Immediately above the clay bed, in the survival interval, an explosive increase in abundance of disaster species Thoracosphaera operculata, $T . \quad$ saxea and Braarudosphaera bigelowi is evidenced. The disaster's blooms are quantitatively evaluated: Thoracosphaerids reach over $80 \%$ and Braarudosphaera bigelowi - up to $20 \%$ from the total specimens. In the Lowermost Danian (NP 1 B. sparsus Zone) many of Cretaceous species practically occur. We still do not know whether these are reworked or if they survived the $\mathrm{K} / \mathrm{T}$ boundary event(s).

In the recovery interval, related to the time of NP 2 (early phase) and NP 3 (late phase) nannofossil Zones, nannofossil assemblages have completely changed. Here a major radiation of newly evolved clades (Cruciplacolithus- lineage, Futuania-Prinsius, Coccolithus-Ericsonia, Cruciplacolithus-Chiasmolithus) is registered.

In conclusion, these changes in calcareous nannofossil assemblages across the $\mathrm{K} / \mathrm{T}$ boundary interval are interpreted as reflecting the short-time global Cretaceous/Tertiary boundary event(s), affected the marine nannoplankton communities. 